\title{
6. Nonstandard employment: Global vision and evidence from China's urban labour market
}

Yongjie Wang

Nonstandard forms of employment have become a feature of contemporary labour markets around the world (ILO 2016). The growth of nonstandard employment (NSE) was noticed as early as the 1970s in developed economies such as Europe, the United States and Australia (Allan 2000; Kalleberg 2000; Adams and Deakin 2014). In Asia, there was also evidence of the development of NSE, the proportion of which increased from 17 per cent to 34 per cent from 1986 to 2008 in Japan, and from 27.4 per cent to 34.3 per cent from 2002 to 2011 in South Korea (Korea Labour Institute 2011; Asano et al. 2013, both cited in Cooke and Brown 2015). In recent years, new jobs and new forms of employment have tended to be more flexible and nonstandard. For example, in Organisation for Economic Co-operation and Development (OECD) countries, more than half of all jobs created since 1995 were nonstandard jobs and NSE accounted for about one-third of total employment in 2013 (OECD 2015). In Europe, the majority of new forms of employment generated since 2000 are nonstandard jobs, such as employee sharing, casual work, mobile work based on information and communication technology (ICT), portfolio work and crowd employment (Eurofound 2015). In the literature on NSE, it is explained as firms' strategies to save costs, attain flexibility and screen candidates for regular positions, and, at the structural level, it has been attributed to an expansion of the service sector, the availability of new technologies and labour market deregulation (Allan 2000; Houseman 2001; Bosch 2004; George and Chattopadhyay 2015). Some studies have described the growth of NSE as a response to strict labour laws and labour market regulations (Schömann et al. 1998; Adams and Deakin 2014; Cooke and Brown 2015; Aleksynska and Berg 2016).

NSE has also become an important feature of China's labour market. Nonstandard forms of employment-such as those based on ecommerce and virtual platforms and tasks - have become widespread and an important source of employment growth in China. In 2017, there were almost 7.2 million labourers employed in the shared economy (economic activities involving online services and transactions), accounting for 9.7 per cent of newly created jobs in China's urban labour market (Information Centre of the State Council and Internet Society of China 2018). In its people's wellbeing policy framework, the Chinese Government has given high 
priority to employment and pursued a proactive employment policy, supporting the development of flexible and new forms of employment (see Xi 2017; State Council of the People's Republic of China 2019).

Nevertheless, NSE is still a relatively new topic within both academic and policy debates in China. So far, there have been few studies of NSE in China. Some studies have investigated new forms of employment (Yang and Wang 2018; Yang et al. 2018; Zhang 2018) or have described NSE or nonstandard features of labour relations in China at a conceptual level (Dong 2008; Li 2011; Ma et al. 2011; Yang and Ma 2014; Qian 2018). There is limited knowledge of China's NSE, its proportion and characteristics. The aim of this chapter is to draw more academic attention to the growth of NSE in China. Studying China's NSE is timely, particularly in an era when forms of employment are becoming more diverse and flexible, and the Chinese Government is supporting the growth of new forms of employment to promote employment growth. A major dilemma accompanying the growth of NSE is how to adapt to and regulate NSE and build a more inclusive and integrated labour market. This is also a global challenge, since standard employment was the norm in past decades and the basis of labour market regulations (Kalleberg 2000). Given the juridical dimension of standard employment, its labourers not only earn regular wages, but also gain access to employment protection and social insurance, whereas NSE tends to be more precarious (Kalleberg 2003; Eichhorst and Tobsch 2014; Adams and Deakin 2014).

Based on its significance and the complexity and precarious nature of NSE, it is important to treat it as a separate employment category and produce targeted policies to adapt to the growth of NSE in China. To explore NSE in China, this chapter will address three questions: What is NSE from the global perspective and in terms of China's background? What are the scale and characteristics of NSE in China? Who are the people most likely to engage in NSE? This study draws on data from the China Urban Labour Survey (CULS) conducted in 2016. The policy implications of this study are summarised in the final section.

\section{What is nonstandard employment?}

Before discussing NSE in China, it is necessary to define NSE at the conceptual level. The term NSE has been used interchangeably with 'nontraditional employment', 'irregular employment', 'atypical employment' and 'nonregular employment'. When used to highlight its precarious and inferior status, NSE is also often labelled 'precarious employment', 'marginal employment' or 'alternative employment', despite the fact the scope of NSE is much wider than these last terms. This section reviews definitions of NSE by both academic and international organisations. 
According to an earlier and widely cited definition of NSE, workers in the sector have limited temporal, physical and administrative attachment to organisationsunlike workers in standard employment, who have fixed working hours, indefinite employment contracts and work at a fixed location, under the direct supervision and administrative control of their employer (Pfeffer and Baron 1988). Standard employment relationships refer to

a stable, socially protected, dependent, full-time job ... the basic conditions of which (working time, pay and social transfers) are regulated to a minimum level by collective agreement or by labour and/or social security law. (Bosch 1986, cited in Bosch 2004)

Kalleberg (2009) maintains that, in a standard employment relationship, workers are assumed to work full-time for a particular employer at the employer's workplace, often progressing up the job ladder within internal labour markets. Adams and Deakin (2014) underscored the economic and juridical dimensions to distinguish between standard and nonstandard employment. Standard employment relationships provide labourers with access not just to income, but also to insurance against labour market risks, while NSE is associated with precariousness (Adams and Deakin 2014).

In reports on NSE released by international organisations, it is usually defined as a part-time, multiparty employment relationship and temporary work that deviates from a full-time, employer-employee bilateral employment relationship and indefinite labour contracts (Eurofound 2015; OECD 2015; ILO 2016). The International Labour Organization (ILO) defines NSE as work that falls outside the realm of standard employment relationships that are full-time, indefinite and part of a subordinate relationship between an employee and an employer (ILO 2016). If standard employment is defined as occurring at a set place of work outside the home, an even broader scope of tasks falls under NSE, including telework and remote work (ILO 2016). According to Eurofound (2015), NSE falls into one or more of the following categories: relationships between employers and employees that are different from the established one-to-one employment relationship; the provision of work on a discontinuous or intermittent basis or for very limited periods, rather than on a continuous or regular basis; and networking and cooperation arrangements between self-employed individuals.

There are common characteristics or essential dimensions of NSE across different contexts, manifested in the temporal, economic, juridical and employment relationship dimensions. Based on a review of definitions of NSE, the following characteristics of NSE are underlined. First, in the temporal dimension, NSE is distinguished by its working hours and the length of the employment relationship or labour contract. Standard employment refers to full-time employment on a regular, stable and continuing basis, whereas NSE refers to part-time employment or full-time work based on temporary or intermittent arrangements. Second, in the 
economic dimension, although employees in standard employment are paid regularly-usually on a biweekly or monthly basis-and have the right to a minimum wage, NSE workers are paid based on workload or tasks and may incur market risk. Third, in the juridical dimension, standard employment is based on the conclusion of legal labour contracts, be they written or verbal, depending on labour contract regulations in different countries. A standard employment relationship is legally and socially protected via employment protection, social insurance and the protection of employees' legal rights. Forth, standard employment is based on a direct and bilateral employment relationship between an employer and an employee. Multiparty employment relationships, such as labour dispatches or employee sharing, which involve three or more parties, are not standard employment arrangements. In addition to thresholds in the temporal, economic, juridical and labour relationship dimensions, NSE also includes a physical dimension and sometimes relies on the support of ICT - for example, mobile phones and personal computers - which may change work patterns and the nature of work relationships (Adams and Deakin 2014; Eurofound 2015).

\section{Defining NSE in China}

Even though there are general principles of NSE, as discussed above, in practice, there are multiple and emerging forms of this kind of employment. There is no official definition of NSE that could be applied across all contexts. Instead, there are variations of NSE across different economic contexts, legislative frameworks and labour market regulations. As noted by Bosch (2004), different legal and welfare regimes and variations in countries' welfare regimes might change the meaning of standard employment and NSE. In considering the employment characteristics and labour market regulations of China, this chapter defines standard employment in China as full-time work based on legal, written and stable labour contracts, be they fixed-term or indefinite, and direct bilateral employment relationships between an employer and an employee. The essential difference of this definition from that of the ILO is defining full-time fixed-term employment as standard. According to the ILO's classification, fixed-term employment is categorised as temporary employment, and is therefore considered as NSE. ${ }^{1}$ Such a classification does not apply to the Chinese context. In China, full-time employment based on fixed-term labour contracts (excluding labour dispatches) should be considered as standard employment for two reasons.

1 According to the ILO (2016), there are four major types of NSE: temporary employment, part-time and on-call work, multiparty employment relationships and disguised employment/dependent self-employment. The category of temporary employment comprises employment based on fixed-term contracts, project or taskbased contracts and seasonal and casual work, including daily work. 
First, fixed-term employment is a mainstream and standard form of employment in China. The ILO categorises fixed-term employment as NSE, primarily because non-fixed-term employment is a prevalent employment arrangement in developed economies. Among OECD countries, the proportion of non-fixed-term employment is very high. The proportion of NSE in some OECD countries-including Australia, the United Kingdom, Norway, Denmark and another nine countries-was above 90 per cent in 2011 and 2012, whereas fixed-term employment is a non-mainstream form of employment (OECD 2014). In China, fixed-term employment is more prevalent. Drawing on data from the CULS for 2010, Wang (2013) finds that, in urban China, the proportion of non-fixed-term (indefinite) employment among migrant labourers and local urban labourers was 19.93 per cent and 44.58 per cent, respectively, whereas that of fixed-term employment was 75.36 per cent and 53.48 per cent, respectively (Wang 2013). This means that fixed-term employment is a common and standard employment arrangement in China.

Second, under current labour market regulations in China, workers under both fixed-term employment and non-fixed-term employment are subject to the same strict protections and have equal labour rights. According to China's Labour Contract Law, enacted in 2008, the establishment of a labour relationship between an employer and an employee occurs at the conclusion of a written labour contract. ${ }^{2}$ The establishment of a labour relationship based on fixed-term and non-fixed-term contracts serves multiple purposes, including the provision of social protection, employment and income security, safe and healthy workplaces, equality of access, and so on (Rubery 2015; ILO 2016). Although China's Labour Contract Law also regulates three special employment arrangements-that is, collective contracts, labour dispatches and part-time employment-fixed-term and non-fixed-term employment are considered standard forms of employment. The strict labour market regulations regarding the conclusion of a labour contract, restrictions on the dismissal of workers, labour rights protection and identification of relevant responsibilities mainly target fixed-term and non-fixed-term employment groups. Du (2014) drew on the OECD's framework to investigate the level of protection and strictness of labour market regulations, examining regulations regarding the conclusion of labour contracts, requisite terms and content of labour contracts and regulations regarding the dismissal of workers and termination of a labour contract. Du (2014) found the framework of China's contemporary labour market regulations provides highlevel employment and social protections, achieving a score of 3.3-higher than the average level of OECD countries (2.3). This means that, compared with developed economies, China's labour market regulations provide even stricter employment and legal protections. Based on this reality and its labour market regulations, fixed-term employment should be categorised as standard in China.

2 Labour Contract Law of the People's Republic of China, available from: www.npc.gov.cn/englishnpc/Law/200902/20/content_1471106.htm. 
Given the above argument, this chapter defines standard employment and NSE in China according to the status of labour contracts. Standard employment refers to full-time employment based on non-fixed-term and fixed-term labour contracts (excluding labour dispatches) and employment of those who work for central and local governments and other jobs in the public sector. Employment falling outside the above realm should be categorised as NSE, such as part-time employment, multiparty employment relationships, temporary employment (project or task-based contracts, seasonal and casual work), platform or virtual employment and self-employment.

\section{Data and sample}

This study draws on data obtained from the CULS conducted by the Institute of Population and Labour Economics at the Chinese Academy of Social Sciences. So far, four rounds of CULS have been conducted. This study draws on the latest data, from the fourth round of the survey, in 2016. It was conducted in six provincial capital cities: Shanghai, Guangzhou, Fuzhou, Wuhan, Shenyang and Xi'an. It is a household-level survey covering labourer' education levels, employment status, previous experience, social protection status, skills, training and other personal information. A probability proportional to size (PPS) sampling method was utilised to select the samples.

This chapter focuses on working-age labourers - that is, those who are currently employed and are aged above 16 years. A study sample of 7,439 individuals was selected, including 1,044 respondents from Shenyang City, 1,335 respondents from Shanghai, 1,229 from Fuzhou, 1,254 from Wuhan, 1,478 from Guangzhou and 1,099 from Xi'an. Among the valid study sample, 57.59 per cent of respondents were male and 42.41 per cent were female. As for residence status, 63.15 per cent of respondents were local urban residents and 36.85 per cent were rural migrants. In terms of hukou (household registration) status, 25.83 per cent of respondents had rural hukou, while 74.17 per cent had urban hukou. The average age of the study sample was 39.04 years, and the average years of schooling among respondents were 12.88. The proportion of those married was 82.88 per cent, while the unmarried accounted for 17.12 per cent. 


\section{Main findings}

\section{Measurement and scale of NSE in China}

In measuring the scale of NSE in China, this study categorises full-time employment based on non-fixed-term employment contracts and fixed-term contracts (excluding labour dispatches) as standard employment, including civil servants in central and local governments and those who are employed in other areas of the public and private sectors. Employment falling outside the above realm was taken as NSE.

Drawing on the CULS data, this study finds that the proportion of NSE among the six cities investigated in 2016 was 34.95 per cent, indicating that NSE has become an important feature of the labour market in China (Wang 2018). The result also reflects a significant regional gap. The proportion of NSE was highest in Wuhan City ( 43.9 per cent), while in Shenyang it was 43.29 per cent, 40.39 per cent in Guangzhou, 38.18 per cent in Xi'an and 34.39 per cent in Fuzhou. The lowest proportion of NSE was in Shanghai, at 22.73 per cent.

\section{Characteristics of NSE in China}

As indicated in the literature on NSE, this form of employment is often associated with precariousness. NSE workers tend to experience wage penalties, poor working conditions, long working hours, few training opportunities and a lack of labour rights and social security protections (Allan 2000; Cooke and Brown 2015). Due to limited temporal, physical and administrative attachments to organisations, NSE workers have weaker attachment to their employers, which may affect their behaviour and performance and may undermine organisational aims (Allan 2000; George and Chattopadhyay 2015). Based on the CULS data, NSE in China demonstrates the following characteristics: low levels of job satisfaction, low wage levels, high levels of overtime, low social insurance coverage and inadequate income protections (Wang 2018).

First, NSE workers tend to have lower levels of job satisfaction. As shown in Table 6.1, when asked about the degree of satisfaction with their current job, the proportion of NSE respondents who were very unsatisfied or unsatisfied with their employment was 0.91 per cent and 11.02 per cent, respectively-much higher than that for labourers in standard employment, which was 0.42 per cent and 5.8 per cent, respectively. The proportion of NSE labourers who were satisfied or very satisfied with their employment was 44.22 per cent and 4.41 per cent, respectively, which was lower than that of labourers in standard employment, which was 57.01 per cent and 6.74 per cent, respectively. 
Second, NSE labourers have lower incomes. The average monthly income of NSE workers was RMB4,806.76 (US\$716), which was RMB1,492.16 lower than that of standard workers. The average monthly income of NSE workers was 76.31 per cent of that of standard employees. The average hourly income of NSE workers was RMB23.34 (about US\$16)—65.71 per cent of that of standard workers (Table 6.1).

Third, working overtime is common among labourers in NSE. The survey data show that urban labourers tend to work long hours_an average of 47.29 hours per week, which is much higher than the 40 hours per week standard regulated by the Chinese Government. ${ }^{3}$ NSE workers put in even longer hours, 54.95 per week-11.74 hours more than labourers in standard employment. With 40 hours per week the standard as regulated by the Chinese Government, the proportion of NSE labourers who worked overtime was 71.32 per cent, while that of employees in standard employment was only 29.52 per cent (Table 6.1).

Table 6.1 Comparison of standard employment and NSE

\begin{tabular}{|c|c|c|c|c|}
\hline & Overall (1) & $\begin{array}{c}\text { Standard } \\
\text { employment (2) }\end{array}$ & NSE (3) & $(3)-(2)$ \\
\hline \multicolumn{5}{|l|}{ Level of job satisfaction (\%) } \\
\hline Very unsatisfied & 0.59 & 0.42 & 0.91 & 0.49 \\
\hline Unsatisfied & 7.65 & 5.80 & 11.02 & 5.22 \\
\hline Neither good nor bad & 33.36 & 30.04 & 39.43 & 9.39 \\
\hline Satisfied & 52.49 & 57.01 & 44.22 & -12.79 \\
\hline Very satisfied & 5.92 & 6.74 & 4.41 & -2.33 \\
\hline \multicolumn{5}{|l|}{ Work compensation and hours } \\
\hline Monthly income (RMB) & $5,781.04$ & $6,298.92$ & $4,806.76$ & $-1,492.16$ \\
\hline Hourly income (RMB) & 31.29 & 35.52 & 23.34 & -12.18 \\
\hline Average working hours (per week) & 47.29 & 43.21 & 54.95 & 11.74 \\
\hline Proportion of overtime work (\%) & 45.57 & 29.52 & 71.32 & 41.80 \\
\hline \multicolumn{5}{|l|}{ Coverage of social insurance (\%) } \\
\hline Pension & 71.43 & 90.41 & 36.09 & -54.32 \\
\hline Basic medical insurance & 69.46 & 88.77 & 33.50 & -55.27 \\
\hline Unemployment insurance & 59.15 & 79.45 & 21.38 & -58.07 \\
\hline Industrial injury insurance & 58.87 & 78.87 & 21.66 & -57.21 \\
\hline Maternity insurance & 52.32 & 71.02 & 17.52 & -53.50 \\
\hline
\end{tabular}

Source: IPLE-CASS (2016).

3 According to regulations on working hours released by the State Council of China in 1994, the regular working hours of a full-time employee are 8 hours per day and 40 hours per week (MoHRSS 1994). 
Fourth, social insurance coverage among NSE workers is lower than that among workers in standard employment. The proportion of employees in standard employment who were covered by a basic pension was 90.41 per cent, while that of NSE employees was only 36.09 per cent. The coverage rates for basic medical insurance, unemployment insurance, industrial injury insurance and maternity insurance for NSE workers were 55.27 per cent, 58.07 per cent, 57.21 per cent and 53.5 per cent lower, respectively, than those of labourers in standard employment, as shown in Table 6.1. The low level of social security coverage is a major area requiring change to improve the status of NSE workers.

Fifth, the proportion of labour union members is lower among NSE labourers. The proportion of labour union members in standard employment was 33 per cent, while that of NSE workers was only 3.68 per cent-implying a low level of representation of NSE workers in such organisations. The proportion of labour union members among workers in standard employment varied across cities, and was highest in Shenyang City, at 58.03 per cent, and lowest in Guangzhou, at 21.19 per cent. As shown in Table 6.2, the proportion of labour union members among NSE labourers was much lower. In spite of the differences between cities, the average proportion of labour union members among those in NSE was only 3.68 per cent. Even in Wuhan, where the proportion of labour union members among NSE workers was the highest, it was only 6.15 per cent. The low proportion of NSE workers in labour unions is not conducive to improving the bargaining power of those workers. Measures should be taken to increase the proportion of labour union membership among NSE employees, to strengthen the diversity of labour unions and include representatives of part-time and dispatch workers in labour unions.

Table 6.2 Proportion of labour union members in standard employment and NSE (per cent)

\begin{tabular}{|l|r|r|r|}
\hline City & Standard employment & NSE & Overall \\
\hline Shenyang & 58.03 & 5.17 & 35.15 \\
\hline Shanghai & 32.97 & 4.24 & 26.44 \\
\hline Fuzhou & 33.66 & 5.40 & 23.95 \\
\hline Wuhan & 31.63 & 6.15 & 20.45 \\
\hline Guangzhou & 21.19 & 0.47 & 12.82 \\
\hline Xi'an & 35.43 & 3.85 & 23.37 \\
\hline Overall & 33.00 & 3.68 & 22.75 \\
\hline
\end{tabular}

Source: IPLE-CASS (2016).

Sixth, among the six cities investigated, the proportion of NSE labourers whose wage was lower than the local minimum standard (7.25 per cent) was higher than that of workers in standard employment (2.42 per cent) (Table 6.3). 
Table 6.3 Proportion of labourers earning less than the local minimum wage (per cent)

\begin{tabular}{|l|r|r|r|}
\hline City & Standard employment & NSE & Overall \\
\hline Shenyang & 5.26 & 8.20 & 6.53 \\
\hline Shanghai & 2.41 & 6.14 & 3.25 \\
\hline Fuzhou & 0.61 & 2.23 & 1.17 \\
\hline Wuhan & 3.63 & 11.83 & 7.20 \\
\hline Guangzhou & 1.07 & 5.96 & 3.02 \\
\hline Xi'an & 1.74 & 5.46 & 3.17 \\
\hline Overall & 2.42 & 7.25 & 4.10 \\
\hline
\end{tabular}

Source: IPLE-CASS (2016).

\section{Who are the workers most likely to engage in NSE in China?}

According to reports from the ILO (2016) and OECD (2015), women, young workers, migrants and those with a low level of educational achievement are most likely to engage in NSE. There are multiple reasons behind the choices of NSE workers. For example, women choose NSE to fit in around their care tasks, while migrant workers choose NSE primarily because of their poor human capital, poor linguistic capability, poor professional networks or weak bargaining power (OECD 2015; ILO 2016).

This chapter finds that, in China's urban labour market, the proportions of senior workers, males, migrant labourers and those with low levels of educational achievement were higher among NSE workers. First, the proportion of senior-age workers is higher among NSE than among standard workers. Drawing on the CULS (IPLE-CASS 2016), the average age of standard workers was 38.35 years, while that of NSE workers was 40.33 years. As shown in Table 6.4, in terms of age distribution, the proportion of workers over the age of 35 among NSE workers is higher than that among workers in standard employment. In particular, for those aged between 45 and 54 , the proportion in standard employment was 21.86 per cent, while that in NSE was 28.03 per cent.

Second, the proportion of men in NSE was higher than that of women. The survey data show that 57.22 per cent of nonstandard employees were men while 42.78 per cent were women. However, gender distribution in NSE was similar to that in standard employment. The proportion of men in standard employment (57.78 per cent) was also higher than that of women (42.22 per cent). The regression analysis shows that gender had no significant impact on the possibility of engaging in NSE (Table 6.6). 
Table 6.4 Worker age distribution in standard employment and NSE (per cent)

\begin{tabular}{|l|r|r|r|}
\hline Age & Standard employment & NSE & Overall \\
\hline $16-24$ & 5.13 & 5.98 & 5.43 \\
\hline $25-34$ & 36.24 & 26.44 & 32.81 \\
\hline $35-44$ & 29.90 & 30.96 & 30.27 \\
\hline $45-54$ & 21.86 & 28.03 & 24.02 \\
\hline 55 and above & 6.88 & 8.59 & 7.47 \\
\hline Overall & 100.00 & 100.00 & 100.00 \\
\hline
\end{tabular}

Source: IPLE-CASS (2016).

Third, labourers with a low level of educational attainment accounted for a higher proportion of labourers in NSE. Data analysis shows the average years of schooling among all workers were 12.88. The average years of schooling among standard employees were 13.97, while among NSE labourers it was only 10.85. As indicated in Table 6.5, 77.87 per cent of NSE labourers had achieved high school education or below, which was much higher than the proportion of those in standard employment (37.24 per cent). The proportion of labourers with tertiary education (college level and above) among NSE labourers was only 22.14 per cent, while that among standard employment labourers was 62.75 per cent (Table 6.5).

Table 6.5 Education distribution of standard employment and NSE labourers (per cent)

\begin{tabular}{|l|r|r|r|}
\hline Education level & Standard employment & NSE & Overall \\
\hline Primary school & 1.73 & 9.07 & 4.29 \\
\hline Junior high school & 11.96 & 39.71 & 21.65 \\
\hline $\begin{array}{l}\text { Senior high school or } \\
\text { technical secondary school }\end{array}$ & 23.55 & 29.09 & 25.48 \\
\hline College & 23.02 & 12.52 & 19.36 \\
\hline Undergraduate & 33.66 & 9.31 & 25.16 \\
\hline Masters degree and above & 6.07 & 0.31 & 4.06 \\
\hline Overall & 100.00 & 100.00 & 100.00 \\
\hline
\end{tabular}

Source: IPLE-CASS (2016).

Fourth, the proportion of NSE workers with rural bukou was higher than those with urban hukou. The survey data show that the proportion of workers with rural bukou in standard employment was 16.17 per cent, while that in NSE was 43.81 per cent. From the regression analysis results shown in Table 6.6, if other conditions are the same and we control the variables of type of employer, industrial sector and city, the following trends are observed. First, the lower the level of educational achievement, the higher is the possibility of labourers engaging in NSE. The probability of engaging in NSE increased by 4.52 per cent for each one-year reduction of schooling. Second, with the increase in workers' age, the probability of engaging in NSE increased by 
0.21 per cent. Third, the possibility of engaging in NSE among unmarried labourers was 8.38 per cent higher than among married labourers. Fourth, gender did not have an evident effect on the probability of engaging in NSE. Finally, hukou status also impacted on the probability of labourers engaging in NSE. If other conditions were the same, the probability of labourers with rural hukou engaging in NSE was 8.85 per cent higher than that of urban hukou holders.

Given the characteristics of labourers who are more likely to engage in NSE, targeted policies and actions are required to broaden the employment opportunities and improve the job quality of those with lower levels of educational achievement, those who are older and unmarried and workers holding rural hukou.

Table 6.6 Factors influencing labourers' participation in NSE (probit model)

\begin{tabular}{|l|r|r|}
\hline & \multicolumn{2}{|c|}{$\begin{array}{c}\text { Dependent variable: Whether or not to engage in NSE } \\
\text { (Yes = 1) (marginal effects) }\end{array}$} \\
\hline Gender (male = 1) & Coefficient & Standard error \\
\hline Years of schooling & -0.0053 & 0.0166 \\
\hline Age & $-0.0452^{\star \star \star}$ & 0.0030 \\
\hline Marital status (married =1) & $0.0021^{\star \star}$ & 0.0010 \\
\hline Hukou status (rural hukou $=1$ ) & $-0.0838^{\star \star *}$ & 0.0232 \\
\hline Type of employer & $0.0885^{\star \star *}$ & 0.0216 \\
\hline Industrial sector & \multicolumn{2}{|c|}{ Controlled } \\
\hline City & \multicolumn{2}{|c|}{ Controlled } \\
\hline Study sample & \multicolumn{2}{|c|}{ Controlled } \\
\hline
\end{tabular}

*** significant at 1 per cent

** significant at 5 per cent

* significant at 10 per cent

Source: IPLE-CASS (2016).

\section{Conclusion}

This study has three major findings, which fill existing knowledge gaps regarding NSE in China and provide evidence for policymakers considering further strategies to adapt to and regulate the growth of NSE in China. First, the proportion of NSE in China's urban labour market was 34.95 per cent, demonstrating the significance of this form of employment in China. The result also reflects a significant regional gap. The proportion of NSE in advanced regions, such as Shanghai, which leads in realising economic transformation and upgrading, was lower than that in other cities. Second, NSE in China demonstrated the following characteristics: low levels of job satisfaction, low wages, high levels of overtime, low social insurance 
coverage and poor wage protection. Third, in China's urban labour market, the proportions of senior-age workers, males, migrants and those with low levels of educational achievement were higher among NSE workers, and workers with these characteristics were more likely to engage in NSE.

Based on these findings, three key issues are highlighted to deal with the growth of NSE in China. First, NSE should be treated as a separate employment category in the design of employment policy and labour market regulations. Although in recent years there has been significant progress, current employment policies and protections mainly target labourers in standard employment, whereas NSE labourers are not subject to employment protection under contemporary labour laws and market regulations. There is still no legal reference for the management of NSE and the protection of the rights of NSE labourers.

Second, job quality assessment and improvement should be emphasised. Compared with standard employment, in NSE, job quality tends to be lower, characterised by low job satisfaction, low wages, high levels of overtime, low social insurance coverage, poor protection of wage rights and interests, and so on. Measures are required to assess and monitor job quality in terms of working hours, wages and social insurance coverage. Regular evaluation and monitoring should be carried out to determine the trends in NSE and form more dynamic monitoring. Multiple measures are required, including legislation, the justice system and labour supervision. Nevertheless, due to the large scale of NSE and its multiple forms, such activities will incur high management costs. How to achieve a balance between improving job quality and promoting employment growth also needs careful consideration.

Third, targeted policies and actions are required to broaden the employment choices for those who are most likely to engage in NSE. It is also necessary to take measures to strengthen the collective bargaining power of NSE workers by enhancing labour union membership at all levels, improving the representation of organisations and absorbing nonstandard workers into labour unions.

There are also a few limitations of this study. Due to the complex and heterogeneous nature of NSE and its emerging forms with the development of new technology, measuring NSE is difficult. The definition of NSE may vary across different contexts or with modifications in the legal framework within one country. The limited availability of data on NSE (Barrientos 2011) is a global challenge to the study of NSE trends. This chapter provides an overview of NSE in China based on evidence from China's urban labour market; nevertheless, multiple sources of data are needed for future studies to observe the trends of NSE in China. 


\section{References}

Adams, Z. and Deakin, S. (2014), Institutional solutions to precariousness and inequality in labour markets, British Journal of Industrial Relations 52(4): 779-809. doi.org/10.1111/ bjir. 12108 .

Aleksynska, M. and Berg, J. (2016), Firms' demand for temporary labour in developing countries: Necessity or strategy?, Conditions of Work and Employment Series No. 77, Geneva: International Labour Organization.

Allan, C. (2000), The hidden organisational costs of using non-standard employment, Personnel Review 29(2): 188-206. doi.org/10.1108/00483480010295989.

Barrientos, S. (2011), 'Labour chains': Analysing the role of labour contractors in global production networks, BWPI Working Paper No. 153, Manchester: Brooks World Poverty Institute. doi.org/10.2139/ssrn.1895292.

Bosch, G. (2004), Towards a new standard employment relationship in Western Europe, British Journal of Industrial Relations 42(4): 617-36. doi.org/10.1111/j.1467-8543. 2004.00333.x.

Cooke, F. and Brown, R. (2015), The regulation of non-standard forms of employment in China, Japan and the Republic of Korea, Conditions of Work and Employment Series No. 64, Geneva: International Labour Organization.

Dong, B. (2008), Nonstandard labor relations, Academic Research 7(July): 50-7.

Du, Y. (2014), International comparison of labor market institutions and its implications for China, Studies in Labor Economics 4(August): 161-92.

Eichhorst, W. and Tobsch, V. (2014), Not so standard anymore? Employment duality in Germany, IZA Discussion Paper No. 8155, Bonn: Institute of Labor Economics.

Eurofound (2015), New Forms of Employment, Luxembourg: Publications Office of the European Union.

George, E. and Chattopadhyay, P. (2015), Non-standard work and workers: Organizational implications, Conditions of Work and Employment Series No. 61, Geneva: International Labour Organization.

Houseman, S. (2001), Why employers use flexible staffing arrangements: Evidence from an establishment survey, Industrial and Labor Relations Review 55(1): 149-70. doi.org/ 10.1177/001979390105500109.

Information Centre of the State Council and Internet Society of China (2018), Annual Report of the Development of Share Economy in China 2018, available from: www.sic. gov.cn/archiver/SIC/UpFile/Files/Default/20180320144901006637.pdf.

Institute of Population and Labor Economics, Chinese Academy of Social Sciences (IPLECASS) (2016), The China Urban Labour Survey (CULS) 2016, Beijing: IPLE-CASS. 
International Labour Organization (ILO) (2016), Non-Standard Employment around the World: Understanding challenges, shaping prospects, Geneva: ILO.

Kalleberg, A. (2000), Nonstandard employment relations: Part-time, temporary and contract work, Annual Review of Sociology 26(1): 341-65. doi.org/10.1146/annurev. soc.26.1.341.

Kalleberg, A. (2003), Flexible firms and labor market segmentation: Effects of workplace restructuring on jobs and workers, Work and Occupations 30(2): 154-75. doi.org/ $10.1177 / 0730888403251683$.

Kalleberg, A. (2009), Precarious work, insecure workers: Employment relations in transition, American Sociological Review 74(1): 1-22. doi.org/10.1177/000312240907400101.

Li, P. (2011), Explorations of nonstandard labor relations in China, Human Resource Development of China (March): 84-6.

Ma, Y., Chen, M. and Yang L. (2011), Investigation and analysis of nonstandard labor relations against circumstances of new law, Human Resource Development of China 8(August): 88-93.

Ministry of Human Resources and Social Security (MoHRSS) (1994), State Council Regulations on Working Hours of Employees, Beijing: MoHRSS, available from: www.mohrss.gov.cn/SYrlzyhshbzb/zcfg/flfg/xzfg/201604/t20160412_237909.html.

Organisation for Economic Co-operation and Development (OECD) (2014), OECD Employment Outlook 2014, Paris: OECD Publishing.

Organisation for Economic Co-operation and Development (OECD) (2015), In It Together: Why less inequality benefits all, Paris: OECD Publishing.

Pfeffer, J. and Baron, J. (1988), Taking the workers back out: Recent trends in the structuring of employment, in B. Staw and L. Cummings (eds), Research in Organizational Behavior. Volume 10, Greenwich: JAI Press.

Qian, Y. (2018), Nonstandard employment and informal employment: Distinction, overlapping and adjustment, China Labor 4(April): 57-62.

Rubery, J. (2015), Re-regulating for inclusive labor markets, Conditions of Work and Employment Series No. 65, Geneva: International Labour Organization.

Schömann, K., Rogowski, R. and Kruppe, T. (1998), Labour Market Efficiency in the European Union: Employment protection and fixed-term contracts, London: Routledge.

State Council of the People's Republic of China (2019), Annual Government Work Report 2019, 5 March, Beijing, available from: www.gov.cn/premier/2019-03/16/content_ 5374314.htm.

Wang, M. (2013), The implementation of China's Labor Contract Law: Problems and policy suggestions, Journal of Guizhou University of Finance and Economics 1(January): 23-31. 
Wang, Y. (2018), Non-standard employment in international perspective and China's interpretation: Scale and characteristics of non-standard employment in China, Studies in Labor Economics 6(December): 95-115.

Xi, J. (2017), Report to the 19th National Congress of the Communist Party of China, 18 October, Beijing, available from: www.gov.cn/zhuanti/2017-10/27/content_5234876.htm.

Yang, H. and Ma, Y. (2014), On the defects of workers' rights protection system and its improvement under non-standard labor relations, Journal of Hunan University of Science \& Technology (Social Science Edition) 1(January): 74-9.

Yang, W. and Wang, Q. (2018), Patterns and determinants of labor supply of digital platform workers: An analysis based on U car-hailing platform drivers, Population Research 4(July): 78-90.

Yang, W., Zhang, C. and Xin, X. (2018), A study on the digital economy paradigm and working relations revolution, Journal of China University of Labor Relations 5(October): 56-60.

Zhang, C. (2018), A study on the current situation of employment and labor relations of the sharing-economy platform: A survey based on platforms in Beijing, Journal of China University of Labor Relations (June): 61-70. 
This text is taken from The Chinese Economic Transformation: Views from Young Economists, edited by Ligang Song, Yixiao Zhou and Luke Hurst, published 2019 by ANU Press, The Australian National University, Canberra, Australia.

doi.org/10.22459/CET.2019.06 